\title{
International Student Mentor Development Study
}

\author{
Shasha Cui \\ University of Rochester, United States \\ Email: scui5@u.rochester.edu \\ Address: 60 Crittenden Blvd, Rochester, NY, USA
}

\section{What is Being Studied?}

With the growing number of international students, US higher education institutions have established peer mentor programs to assist first year international students' successful transition to Western academic success, American life and enhance their satisfaction with cultural adjustment experience (Geelhoed, Abe, and Talbot 2003).

Reviews of the past 30 years of literature on peer mentoring for first-year college students reveal a long list of benefits of peer mentor programs including the increase of retention rates, sense of belonging, and students successful transition to new academic and social environments (Beltman and Schaeben 2012; Colvin and Ashman 2010; Crisp and Cruz 2009; Gershenfeld 2014; Jacobi 1991; Terrion, Philion and Leonard 2007). Studies on international student peer mentor programs also confirm that these programs lead to positive impacts on first-year international mentees such as improving English language proficiency, making new friends, and attending social activities with people from other ethnic groups (Gresham and Clayton 2011; Woods, Poropat, Barker, Hills, Hibbins, and Borbasi 2013).

Peer mentorship programs are often promoted as reciprocal, where both mentors and mentees could both benefit from learning and development experience (Colvin and Ashman 2010). However, the majority of research focus on the positive impact for mentees, while few (Haggard, Dougherty, Turban, and Wilbanks 2011; Heirdsfield, Walker, Walsh, and Wilss 2008) have focused on the experiences and outcomes for mentors. There is especially a dearth of research that investigates the international student peer mentors themselves and how their perceptions of their experiences being international peer mentors during the mentoring process.

\section{How the research contributes to comparative and international higher education?}

This research study is going to fill the gap and contribute to international higher education by focusing on what international student peer mentors learn from their mentoring experiences and how the experiences impact their personal and professional growth. This research paper focuses on those students who serve as mentors, instead of students who are being mentored. The research project specifically seeks to address the following questions: How do student mentors perceive and value the experiences of being peer mentors for international students? How does the international student peer mentor program contribute to mentors' personal and professional development?

\section{How it is Being Studied?}

A case study research design will be selected for this research and guide research methods since case studies are based on an in-depth investigation of a single individual, group, or event-a phenomenon within its real-life context (Yin 2003). In this research, a case study is an ideal research strategy to identify how the experiences of international student mentors and their perceptions of being mentors for first-year international students.

This case study will use multiple data including interviews and document review. Participants in the study will be the international student peer mentors 2019 cohort from the international peer mentor program at a four-year private, 
nonprofit research institution located in the east coast. The total number is 27 including 19 females and 8 males. All student participants were enrolled in bachelor's programs with five seniors, eight juniors, and fourteen sophomores.

I will also conduct individual interviews as a primary data collection method to get more depth and details on international student peer mentors' perceptions. Participants will complete a face-to-face, semi-structured interview and answer several open-ended questions. The researcher will ask follow-up questions based on their answers for helping clarification of their responses. The interview will begin with the purpose of the study, RSRB notification (how the interview will be used, how long the interview will take, confidentiality, and permission to audio-recorded), and participants' demographic questions (gender, ethnicity, international student status, primary major and etc.) to create a rapport with the participants. There will be an opportunity for the participants to choose their pseudonym to feel more comfortable with the interview process (Rubin and Rubin 2011). Table 1 shows several interview questions as examples.

Table 1: International Student Mentors Interview Questions Examples

\begin{tabular}{|l|}
\hline Interview Questions Examples \\
\hline What are your reasons for being a mentor? \\
\hline How would you describe your experience with students from different cultural backgrounds? \\
\hline Tell me about your relationship with your mentees? \\
\hline Being a mentor has helped you gain/improve any skills? \\
\hline Tell me about what challenges you encountered? Any lesson learned? \\
\hline In what way do you think being a mentor can help in your future career? \\
\hline Has being a mentor been a worthwhile experience? If so, how? If not, why? \\
\hline
\end{tabular}

Reviewing existing documents is a commonly used data collection method in case study (Hancock and Algozzin 2006). Documents will include international peer mentors training materials, resources from the program website, and events reports that could support a better understanding of the program' background information, and to enrich data collected through interviews (Hancock and Algozzin 2006).

The subsequent data analysis includes transcribing the interviews; open/ line by line coding; creating codes and developing broader categories; and connecting codes to form final themes. An open coding approach will be used initially. In the open coding process, also known as initial or line-by-line coding, the researcher will read each line and identify words and phrases that capture meanings. In the second-round coding process, the researcher will analyze the list of initial codes to identify connections to build categories and then group codes together to form final themes. The coding process creates the categories reflecting the significant experiences and feelings of the interviewee. The researcher will be open to emerging codes during the analysis and to use codes to answer the research questions when developing themes (Saldaña 2013).

\section{What the main take-away of the research will be?}

The purpose of this study is to examine experiences as international student mentors, how the experiences impact their personal growth and professional development, and how their plans to apply the skills and knowledge they learned from the mentoring experience to their daily life and future career. In addition, since this research studies those 
students' mentors not mentees, intentional efforts should be given to design and create more activities and workshops to help student reflect their peer mentoring experiences.

\section{References}

Beltman, Susan, and Marcel Schaeben. 2012. "Institution-Wide Peer Mentoring: Benefits for Mentors." The International Journal of the First Year in Higher Education 3(2): 157-173.

Colvin, Janet W., and Marinda Ashman. 2010. "Roles, Risks, and Benefits of Peer Mentoring Relationships in Higher Education." Mentoring \& Tutoring: Partnership in Learning 18(2): 121-134.

Crisp, Gloria, and Irene Cruz. 2009. "Mentoring College Students: A Critical Review of the Literature Between 1990 and 2007." Research in Higher Education 50(6): 525-545.

Geelhoed, Robyn J., Jin Abe, and Donna Talbot. 2003. "A Qualitative Investigation of US Students' Experiences in an International Peer Program." Journal of College Student Development 44(1): 5-17.

Gershenfeld, Susan. 2014. "A Review of Undergraduate Mentoring Programs." Review of Educational Research 84(3): 365-391.

Gresham, Ruth, and Veronica Clayton. 2011. "Community Connections: A Program to Enhance Domestic and International Students' Educational Experience.” Journal of Higher Education Policy and Management 33(4): 363374.

Hancock, D., and Algozzine, R. 2017. Doing Case Study Research: A Practical Guide for Beginning Researchers ( $3^{\text {rd }}$ ed.). New York, NY: Teachers College Press.

Haggard, Dana L., Thomas W. Dougherty, Daniel B. Turban, and James E. Wilbanks. 2011. "Who Is a Mentor? A Review of Evolving Definitions and Implications for Research." Journal of Management 37(1): 280-304.

Heirdsfield, Ann M., Sue Walker, Kerryann Walsh, and Lynn A. Wilss. 2008. "Peer Mentoring for First-Year Teacher Education Students: The Mentors' Experience." Mentoring \& Tutoring: Partnership in Learning 16(2): 109-124.

Jacobi, Maryann. 1991. "Mentoring and Undergraduate Academic Success: A Literature Review." Review of Educational Research 61(4): 505-532.

Rubin, Herbert J., and Irene S. Rubin. 2011. Qualitative Interviewing: The Art of Hearing Data ( $3^{\text {rd }}$ ed.). Thousand Oaks, CA: Sage.

Saldaña, Johnny. (2013). The Coding Manual for Qualitative Researchers (2 ${ }^{\text {nd }}$ ed.). Thousand Oaks, CA: Sage.

Terrion, Jenepher L., Ruth Philion, and Dominique Leonard. 2007. "An Evaluation of a College Peer-Mentoring Training Programme." International Journal of Evidence Based Coaching and Mentoring 5(1): 42-57.

Woods, Peter, Arthur Poropat, Michelle Barker, Ruth Hills, Ray Hibbins, and Sally Borbasi. 2013. "Building Friendship Through a Cross-Cultural Mentoring Program." International Journal of Intercultural Relations 37(5): 523-535.

Yin, Robert. 2014. Case Study Research: Design and Methods (5th ed.). Thousand Oaks, CA: Sage. 